\title{
Ecology, Diversity and Conservation Priorities of Cave Dwelling Fauna in Mandaramnuwara Cave, Nuwara Eliya District
}

Munasinghe C.S. ${ }^{*}$ and Ranawana K.B.

\author{
Department of Zoology, University of Peradeniya, Peradeniya, Sri Lanka \\ *chathu8810@gmail.com
}

\begin{abstract}
Cave biodiversity studies are scarce in Sri Lanka though caves support large number of species. Formation of a cave takes thousands or millions of years. Mandaramnuwara cave which is a crystalline limestone cave comprised of beautiful formations of Stalactites. The cave is located in the wet zone of Sri Lanka where the annual rainfall is between 2000-2500 $\mathrm{mm}$. Field studies were carried outfrom September 2012 to September 2013 to assess the diversity of bats, birds, herpatofauna and macroinvertebrates. Acave biodiversity database including species richness and description on cave fauna was developed to carry out an ecological survey that will lead to identify the factors which contribute to cave fauna and to improve cave fauna conservation.
\end{abstract}

Throughout the study period transect walks were carried out inside the cave chambers and fauna were recorded in relation to their habitat occupation by direct observation. Random samples were taken for identification purposes. Cave environmental conditions such as light intensity, temperature, humidity and $\mathrm{pH}$ of dripping waterwere recorded. The inner space of the cave has been separated into three large chambers. The entrance zone was mainly occupied by Pseudophilautus macropus. Breeding colony consisting of 34 nests of Aerodramus unicolor was observed in the twilight zone. Endemic snail Ravana politissima colony was observed inside the dark zone. Cave crickets were the most abundant arthropod. Most abundant vertebrate species were Rhinolopus rouxii and Miniopterus schreibersii.

Microchiropterans and the Indian swiftlet species prey upon insects contributing to the forest insect population control. The recorded $\mathrm{pH}$ of the water inside the cave was 4.6. Humidity was $84.3 \%$. The average temperature was $19.6{ }^{\circ} \mathrm{C}$. The information provided by the cave biodiversity data base can be used as baseline information for cave fauna conservation and management, cave eco-tourism and further investigations of cave habitats.

Keywords: Miniopterus schreibersii, Ravana politissima, Aerodramus unicolor, Biodiversity, Eco-tourism, Cave 